\title{
OYSTER REARING ON THE RIVER YEALM
}

\author{
By Douglas P. Wilson, M.Sc., F.R.P.S. \\ Naturalist at the Plymouth Laboratory
}

In a recent issue of this fournal Dr Hughes (1940) published records of a successful attempt to rear oysters in tanks on the River Yealm during the summer of 1939. In this paper he referred to plans for the following year, and it therefore seems desirable to record a few notes on the I940 season.

Since Dr Hughes left Plymouth I have kept in touch with Mr J. Kingcome, the owner of the fishery, and from time to time have visited his tanks and proffered technical advice. In this I have had the willing co-operation of $\mathrm{Mr} \mathrm{H}$. A. Cole of Conway whenever his opinion has been sought. Mr Kingcome has most readily adopted suggestions we have made, and it is to his careful attention and unremitting work that the successful results here recorded are due.

\section{FURTHER HISTORY OF THE I939 SPAT}

Dr Hughes mentioned that in August 1939 some of the larger spat were detached from the tiles and placed in cages in the estuary of the river. At the time of writing (mid-October 1940) these range from 4.5 to $8 \mathrm{~cm}$. in diameter. The remainder of the spat spent the winter on the tiles in tank C (Hughes, 1940, Fig. I), being given almost daily changes of water from the estuary. They were detached from April to July 1940 and placed like the others in wire-meshed cages just above low-water mark spring tides. These oysters have by no means reached the size of those which have been out since August I939, the size range being $2-4 \mathrm{~cm}$. in diameter.

It is difficult to make a reliable estimate of the number of young oysters now in the cages, all of them from the 1939 spatfall. Mr Kingcome believes there are 20,000-30,000; this figure seems to me to be reasonable. They are in splendid condition and there is every prospect of eventually bringing them to marketable size.

\section{THE I940 Spatfall}

Rearing has again been successful under quite different weather conditions. In 1939 there was much rain and heavy cloud, but this year has been outstanding for an almost unbroken period of fine weather from May to September, although heavy rain occurred once or twice during the breeding period. At Conway spat settlement has occurred over a wide range of meteorological conditions (Cole, 1936). As before, tank A was used for breeding and the water in it enriched by Cole's method (1938). The bottom arrangements were 
similar to those of last year, the stock oysters lying on slatted trays covered with large flat tiles. Smaller flat tiles were leant up against the sides of the tank at the bottom, while others were propped against one another in rows of inverted V's. In addition some broken curved tiles were piled on the bottom. The tank was flooded from the estuary on June I2 and enrichment with crab meat began a week later. Larvae were first noticed on June 23 (the same date as last year) but may have been present earlier. About this time several bundles of curved tiles were suspended a short distance below the surface. It had been the intention to hang in this way the majority of the limed tiles used for spat collection but unfortunately there was at the time a shortage of curved ones, and for this reason many flat tiles, which are not easy to suspend, were placed on the bottom. Mr Kingcome also scattered a large number of oyster shells after the tank had been filled: most of them reached the bottom white sides uppermost. Some bundles of shells were hung in net bags at the sides of the tank.

The water in the tank was throughout clearer than in 1939 and was so on the day it was put in. Suitable flagellates were present whenever the water was examined, but on July 15 and August 9 the population appeared sparser than usual. On each of these dates two and a half to three litres of a thick culture of Flagellate "I" was poured in. This culture had been prepared-in readiness should it be needed-from a sample culture sent from Port Erin, where the species had proved to be excellent food for oyster larvae (Bruce et al., 1940). Dr Bruce and Dr Parke kindly forwarded this culture at short notice. It is possible to question the value of these additions, but as data for a satisfactory discussion are lacking it can only be remarked that they possibly ensured the presence of a specially good food, in greater or lesser amount, depending on the extent to which multiplication of the added species took place.

Throughout the rearing the $p \mathrm{H}$ was not known to rise above $8 \cdot 7$ (corrected). Whenever a tendency to increased alkalinity was manifest enrichment was discontinued for a time. Temperatures were not taken regularly.

The first spat settled sometime not later than the first week in July and settlement continued into August. Early in the latter month, before the spat were able to settle too thickly, some of the suspended tiles were removed to tank B. Here they were given daily changes of water from the estuary. About the same time the breeding tank was topped with sea water from the estuary to make up for evaporation loss and leakage. It was emptied on August I5, when the tiles remaining in it were removed to tank $\mathrm{C}$, there to receive daily changes of tidal water. Examination of the tiles during removal amply confirmed the findings of Cole \& Jones (1939) that the larvae tend to settle high and in the darker places. The suspended tiles were well covered with spat, but the largest spat, up to $2 \mathrm{~cm}$. in diameter, were on the flat tiles on the bottom. The better the under sides of these latter had been shielded from the light, the more thickly were they covered with spat, although they did not 
generally bear as many as did the suspended tiles. Illumination of the under surfaces of some of the flat tiles would be assisted by light reflected from the white oyster shells scattered over the bottom. There were algal growths on the under sides of the tiles with fewest spat. Very few spat settled on the oyster shells lying on the bottom: there were rather more on the shells hung in net bags. In future, after this experience, oyster shells will not be scattered over the tank bottom and every effort will be made to hang the main collectors close to the surface and to keep their under sides well shaded.

At the present time (mid-October 1940) large spat are $3 \mathrm{~cm}$. in diameter with occasional ones as big as $3.5 \mathrm{~cm}$. Some have already been chipped off the tiles and placed in wire cages in the estuary. The majority are, of course, smaller than this; $\mathrm{I}-2 \mathrm{~cm}$. across are very common, but many are still only I or $2 \mathrm{~mm}$. They will remain on the tiles over the winter, most of them in tank $\mathrm{C}$, but a few bundles have been hung on poles well above the mud near low-water mark.

A few spat have died, but the proportion is insignificant. We believe that this year's spat are more numerous, and on the whole larger at corresponding dates, than last year's.

It is reasonable to expect that the rearing of oysters on the River Yealm will become an annual routine. From a commercial point of view this will considerably enhance the value of the fishery by reducing, perhaps eliminating, the necessity of importing foreign brood; while for the immediate future it will overcome, partially at any rate, difficulties caused by the present impossibility of obtaining brood oysters from Brittany.

\section{REFERENCES}

Bruce, J. R., KNight, M. \& PARKe, M. W., I940. The rearing of oyster larvae on an algal diet. Fourn. Mar. Biol. Assoc., Vol. xxiv, pp. 337-74.

Cole, H. A., I936. Experiments in the breeding of oysters (Ostrea edulis) in tanks, with special reference to the food of the larva and spat. Min. Agric. and Fish., Fish. Invest., Ser. II, Vol. xv, No. 4.

— 1938. A system of oyster culture. Fourn. Cons. Int. Explor. Mer, Vol. XIII, pp. $22 \mathrm{I}-35$.

Cole, H. A. \& Jones, E. W. K., I939. Some observations and experiments on the settling behaviour of larvae of Ostrea edulis. Fourn. Cons. Int. Explor. Mer, Vol. XIV, pp. 86-I05.

Hughes, E., I940. The breeding of oysters in tanks. Fourn. Mar. Biol. Assoc., Vol. xxIV, pp. 543-47. 